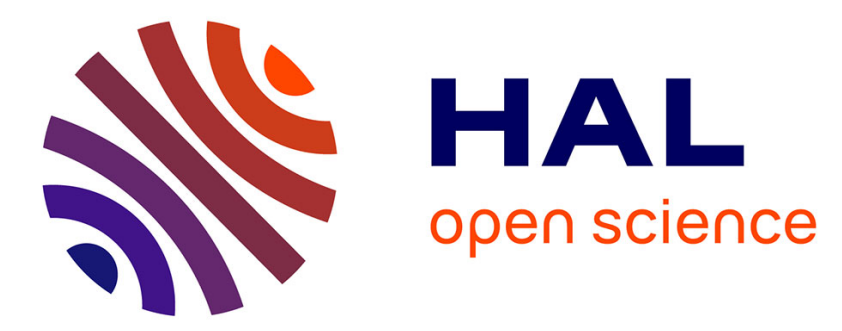

\title{
8000 years of vegetation history in the northern Iberian Peninsula inferred from the palaeoenvironmental study of Zalama ombrotrophic bog (Basque-Cantabrian Mountains, Spain)
}

Sebastián Pérez Díaz, J.A. Lopez Saez, Xabier Pontevedra-Pombal, Martin Souto-Souto, Didier Galop

\section{To cite this version:}

Sebastián Pérez Díaz, J.A. Lopez Saez, Xabier Pontevedra-Pombal, Martin Souto-Souto, Didier Galop. 8000 years of vegetation history in the northern Iberian Peninsula inferred from the palaeoenvironmental study of Zalama ombrotrophic bog (Basque-Cantabrian Mountains, Spain). Boreas, 2016, 45 (4), pp.658-672. 10.1111/bor.12182 . hal-01450967

\section{HAL Id: hal-01450967 https://hal.science/hal-01450967}

Submitted on 31 Jan 2017

HAL is a multi-disciplinary open access archive for the deposit and dissemination of scientific research documents, whether they are published or not. The documents may come from teaching and research institutions in France or abroad, or from public or private research centers.
L'archive ouverte pluridisciplinaire HAL, est destinée au dépôt et à la diffusion de documents scientifiques de niveau recherche, publiés ou non, émanant des établissements d'enseignement et de recherche français ou étrangers, des laboratoires publics ou privés. 
BOREAS

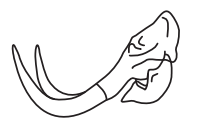
Pérez-Díaz, S., López-Sáez, J. A., Pontevedra-Pombal, X., Souto-Souto, M. \& Galop, D. : 8000 years of
vegetation history in the northern Iberian Peninsula inferred from the palaeoenvironmental study of the Zalama
ombrotrophic bog (Basque-Cantabrian Mountains, Spain). Boreas. 10.1111/bor.12182. ISSN 0300-9483.

This paper focuses on pollen, spores, non-pollen palynomorphs (NPPs) and certain geochemical elements from the ombrotrophic blanket bog of Zalama (Basque-Cantabrian Mountains, northern Iberian Peninsula), with the support of a robust chronology based on $17 \mathrm{AMS}{ }^{14} \mathrm{C}$ dates. The main results related to the last 8000 years show that, during the early middle Holocene, pines and deciduous forests were the most extensive tree formations. At the beginning of the succession, pines reach $44 \%$, showing regional presence, whereas after $7600 \mathrm{cal}$. a BP, deciduous forests were particularly abundant. From $c .6500 \mathrm{cal}$. a BP the pollen diagram constructed from our samples shows the first anthropogenic evidence, linked with the new economic practices related to the Neolithic of the Basque-Cantabrian Mountains. From 3300 cal. a BP the expansion of Fagus sylvatica is particularly clear, and has since then become one of the dominant forest species in this region. We also discuss the Holocene evolution of other noteworthy plant communities in southwestern Europe, such as Taxus baccata, Juglans and shrublands.

Sebastián Pérez-Díaz (sebas.perezdiaz@gmail.com), Dpto. de Geografía, Prehistoria y Arqueología, Facultad de Letras, Universidad del País Vasco Francisco Tomás y Valiente, s/n. Apdo. 2111, 01006 Vitoria-Gasteiz, Spain; José Antonio López-Sáez, Grupo de Investigación Arqueobiología, Instituto de Historia, Centro de Ciencias Humanas y Sociales, Consejo Superior de Investigaciones Científicas (CSIC), Albasanz 26-28, 28037 Madrid, Spain; Xabier Pontevedra-Pombal, Dpto. de Edafología y Química Agrícola, Universidad de Santiago de Compostela, Lópe Gómez de Marzoa s/n. Campus Vida, 15782 Santiago de Compostela, Spain; Martín Souto-Souto, Dpto. De Botánica, Universidad de Santiago de Compostela, Lópe Gómez de Marzoa s/n. Campus Vida,15782 Santiago de Compostela, Spain; Didier Galop, GEODE, UMR 5602 CNRS Université Toulouse 2 Jean Jaurès 5, Allées A. Machado-31058, Toulouse Cedex 9, France; received 8th May 2015, accepted 3rd March 2016.
Peatlands have long been studied in the scientific literature from two basic perspectives: (i) their function as 'islands of biodiversity', i.e. refuges of particularly vulnerable species, and (ii) their use as palaeoenvironmental archives. These natural deposits can be interpreted from many different viewpoints, very interesting for a proper understanding of past climatic, biotic and cultural records (Barber 1993; Lappalainen 1996; Chambers \& Daniell 2010; de Jong et al. 2010). In this sense, ombrotrophic bogs, such as the Zalama peat bog presented in this work, are especially noteworthy deposits. Their water regime and nutrient supply are derived directly and exclusively from precipitation (Lindsay 1995). As a result, they are oligotrophic and usually highly acidic environments, ensuring good overall preservation of organic matter (Pontevedra-Pombal et al. 2006, 2013). These characteristics are critical in making ombrotrophic peatlands excellent palaeoenvironmental archives, which yield data on global climate changes as well as on the impacts of mining, agriculture and livestock.

The area surrounding the Zalama peat bog, in the Basque-Cantabrian Mountains (northern Iberian Peninsula) is also of biogeographical interest because it acts as the border between the Eurosiberian and Mediterranean regions. The existence of several mountain barriers parallel to the coastline limits the progres- sive arrival of Atlantic moisture, favouring complex and rich floristic variability (Aseginolaza et al. 1996). Therefore, this mountain region currently has a rich variety of landscapes, where floristic elements typical of the moist conditions of the Atlantic area coexist with species better adapted to the continental climate on the northern Spanish plateau. It is also a relatively unknown region from the palaeoenvironmental standpoint owing to the scarcity of palaeobotanical studies (Iriarte 2008; Pérez-Díaz et al. 2015). The only palynological research conducted in the area to date was carried out in the nearby peat bog of Los Tornos (Peñalba 1989, 1994; Muñoz-Sobrino et al. 2005). Some archaeobotanical studies (pollen, charcoal, seeds) have also been carried out at archaeological sites located in the bottom of the valleys, such as El Mirón (Iriarte 2012; Peña-Chocarro 2012; Zapata 2012), Cotobasero (Zapata 2002), La Boheriza (Iriarte 1995) and La Cabaña (Iriarte 1999). In short, all these factors, i.e. its nature as an ombrotrophic bog, its geographical location and the scarcity of palaeobotanical research in this area, make the Zalama peat bog extremely valuable for evaluating the landscape, climate conditions and human pressure during the Holocene.

In this paper, we discuss the Holocene evolution of the vegetation in the Basque-Cantabrian region over the last 8000 years. For this, we present a high-resolu- 
tion study of pollen grains, spores and non-pollen palynomorphs, as well as geochemical data of trace elements from the ombrotrophic bog of Zalama (BasqueCantabrian Mountains, northern Iberian Peninsula), this being probably the most southwesterly recorded example of a blanket bog in Europe (Heras \& Infante 2005).

\section{Study area}

The study site is the peat bog of Zalama (latitude $43^{\circ} 8^{\prime} 6^{\prime \prime} \mathrm{N}$, longitude $3^{\circ} 24^{\prime} 35^{\prime \prime} \mathrm{W}$, altitude $1330 \mathrm{~m}$ a.s.1.), located in the vicinity of a peak of the same name, in the southwesternmost corner of the Basque-Cantabrian Mountains (Ordunte Mountains, Basque Country, northern Iberian Peninsula). It is located on a gentle, domed hill on the watershed between the Cantabrian and Mediterranean hydrographic areas (Fig. 1A). This blanket bog is located near the main summit and is unaffected by water movement in streams or overland flow. The peat rests directly on periglacial deposits with quartzite fragments and therefore there is no other organic soil horizon (Fig. 1B; Heras \& Infante 2004). Originally covering an area of 5 ha, it has been badly affected by fires used by cattle breeders to control pastures (Heras \& Infante 2005). Today the burnt area is occupied by bare rock and mineral soil. The blanket bog still covers 2.5 ha (Heras \& Infante 2004), and today is the subject of a major restoration project (Aguirre-Pascual 2011). The predominant geological bedrock is made up of Lower and Upper Cretaceous sedimentary rocks (Middle and Upper Albian-Lower Cenomanian) and sandstones with abundant quartz grains (Garrote et al. 1992).

The peat bog is located in an Atlantic climatic area. The nearest weather station (Cerroja) is located $10 \mathrm{~km}$ to the north. In 2014 the measurements indicated an average yearly precipitation of $1341 \mathrm{~mm}$ for a total of 185 rainy days, and a mean annual temperature of $13.7^{\circ} \mathrm{C}$ (Euskalmet 2011). However, this station is located at a much lower elevation (677 $\mathrm{m}$ a.s.1.); at higher elevations rainfall is presumably heavier. It is also important to note that mist is frequently present on the nearby peaks even in summer, owing to the orographic barrier of the Basque-Cantabrian Mountains to the moist air from the Bay of Biscay. This constant moisture throughout the year is essential for the good preservation of the peat bog.

The current vegetation of the peat bog is composed of a dense peaty moorland of purely ombrotrophic characteristics, dominated by Calluna vulgaris, with Erica tetralix, E. cinerea, Molinia caerulea, Daboecia cantabrica, Sphagnum rubellum, Juncus squarrosus, Ulex gallii and Eriophorum vaginatum (Uribe-Etxebarria et al. 2006). There are also communities of Pteridium aquilinum, a heliophilous fern that sometimes grows on bogs (Fig. 1C). In the vicinity, the current forests are restricted to lower elevations (Bariego \& Gastón 2002), with acidophilous beech forests composed of Fagus sylvatica, Ilex aquifolium, Vaccinium myrtillus, Deschampsia flexuosa, Blechnum spicant, Veronica officinalis and Euphorbia dulcis on the northern slopes. The southern slopes, where the insolation is greater, have Quercus pyrenaica forests with Pseudoarrhenatherum longifolium, Pteridium aquilinum, Arenaria montana and Potentilla erecta, as well as scattered Scots pine (Pinus sylvestris) stands on the sunny slopes (Aseginolaza et al. 1996).

\section{Material and methods}

\section{Coring and sampling}

The core was taken using a Wardenaar corer $(10 \times 10 \times 100 \mathrm{~cm}$; Wardenaar 1987) for the first $100 \mathrm{~cm}$ and a Russian peat sampler (GYK type, $50 \mathrm{~cm}$ length; $5 \mathrm{~cm}$ in diameter) for the rest. The coring point was located in the centre of the peat bog, from where a core with a total length of $232 \mathrm{~cm}$ was extracted (Table 1). Contiguous sampling was performed in the uppermost $30 \mathrm{~cm}$, where samples were taken every centimetre. The rest of the core samples were taken every $2 \mathrm{~cm}$. Two surface samples were also taken at the peat-vegetation interface. A total of 131 samples was analysed.

\section{Chronology}

Selected peat samples were sent to Angström Laboratory of Uppsala University (Sweden) and Centro Nacional de Aceleradores of Sevilla University (Spain) for radiocarbon dating, in order to establish patterns of bog development. Chronology was based on 17 accelerator mass spectrometry (AMS) radiocarbon dates on peat material (Table 2). The dates were calibrated using the CALIB 7.1 radiocarbon calibration program with the IntCal13 curve (Reimer et al. 2013). An age/depth model (Fig. 2) was produced using ClaM 2.2 software (Blaauw 2010), applying a smooth spline solution. Confidence intervals of the calibrations and the age/depth model were calculated at $95 \%(2 \sigma)$ with 1000 iterations. The calendar scale was cal. a BP.

\section{Pollen and NPP analyses}

A total of 131 samples (each $1 \mathrm{~cm}^{3}$ in volume) was used for the palynological study. All of the palynological samples were chemically treated following Girard \& Renault-Miskovsky (1969), with the samples being concentrated in a high-density Thoulet solution (Goeury \& de Beaulieu 1979). Small aliquots of the residues were mounted in glycerine jelly, sealed with Histolaque. Pollen and spores were identified according to Fægri \& Iversen (1989), Moore et al. (1991) and Reille (1999). Non-pollen palynomorphs were identified according 


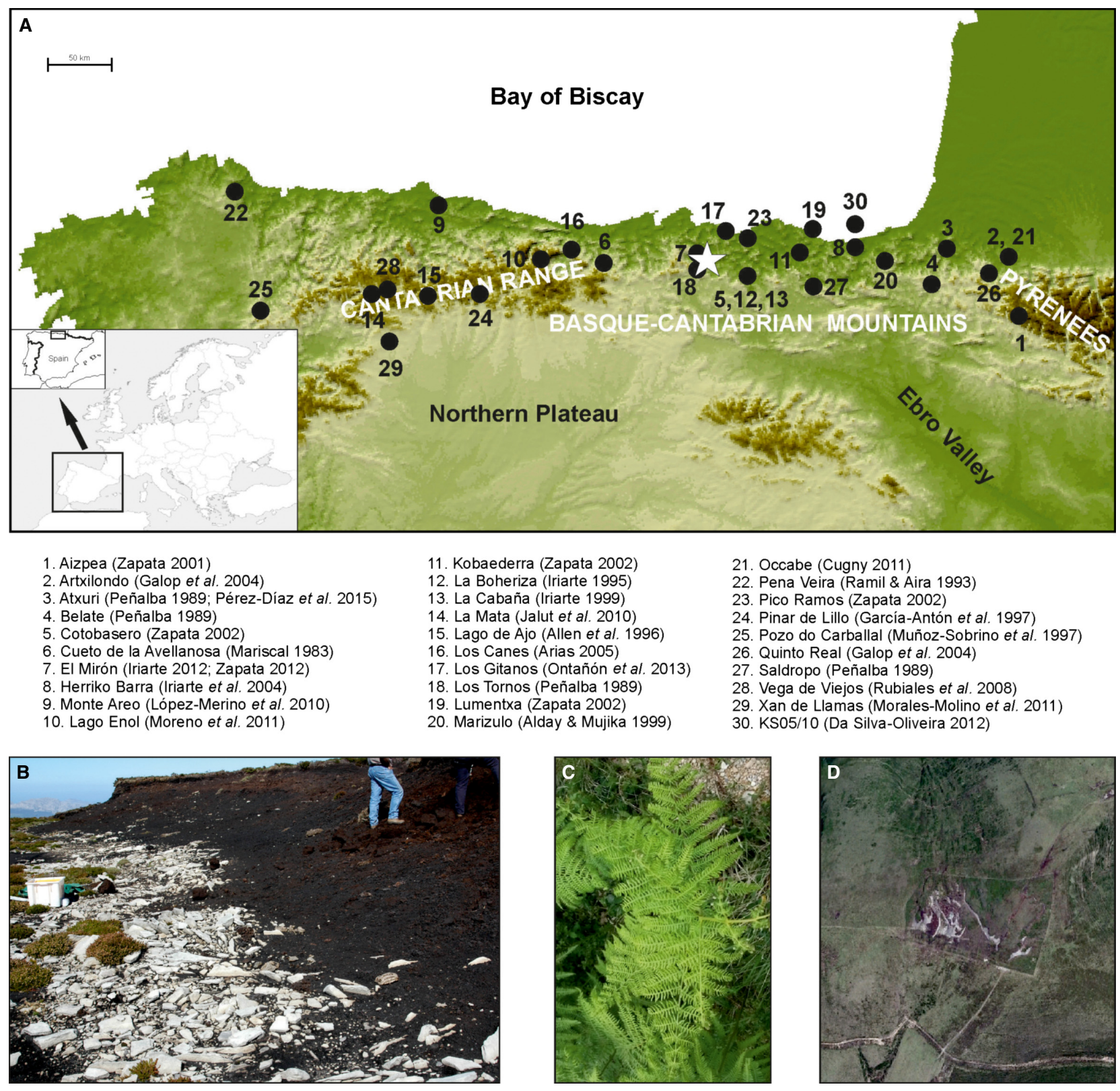

Fig. 1. Study area. A. Map indicating the location of the peat bog of Zalama (white star) and the other sites mentioned in the text (black points). B. Image of the peat bog of Zalama (Patxi Heras). C. Image of Pteridium aquilinum. D. Aerial view of the peat bog of Zalama.

to van Geel (1978, 2001, 2006); van Geel et al. (1981, 1989, 2003) and Cugny (2011). In each sample a minimum of 500 terrestrial pollen grains was counted. Cyperaceae, aquatics and spores were excluded from the pollen sum to avoid over-representation (Wright \& Patten 1963). A pollen diagram (Fig. 3) was produced using the TILIA 2.0 and TGVIEW programs (Grimm 1992, 2004). Local pollen assemblage zones (LPAZs) were constructed on the basis of agglomerative constrained cluster analysis of incremental sum of squares (CONISS) with square-root-transformed percentage data (Grimm 1987).

\section{Elemental geochemistry}

Mineral contributions to bogs can be assessed using reference lithogenic elements present in rocks and soils. It can be assumed that variations in the trace elements in the ombrotrophic peat profile reasonably reflect fluctuations in the deposition of atmospheric soil dust (ASD) (Shotyk 1996; Pontevedra-Pombal et al. 2013). Titanium (Ti) and vanadium (V) are such elements. The total content of these elements was determined in the peat as a proxy of soil erosion. We performed a statistical normalization of the element content (Z-scores, 
Table 1. Morphostratigraphy of the peat section of Zalama peat bog. VP = von Post scale (von Post 1937); IP = sodium pyrophosphate index (Lynn et al. 1974; Soil Survey Staff 1975).

\begin{tabular}{|c|c|c|c|}
\hline Depth (cm) & $\begin{array}{l}\text { Morphostratigraphical } \\
\text { features }\end{array}$ & VP & IP \\
\hline $0-6$ & Vegetation-peat interface & H1 & - \\
\hline $6-12$ & Brown, dry and compact peat & $\mathrm{H} 2$ & Fibric \\
\hline $12-18$ & $\begin{array}{l}\text { Brown to dark brown, } \\
\text { dry and compact peat }\end{array}$ & $\mathrm{H} 4$ & Hemic-Fibric \\
\hline $18-32$ & Reddish brown peat & $\mathrm{H} 2$ & Fibric \\
\hline $32-48$ & Dark brown peat & H5 & Sapric-Hemic \\
\hline $48-86$ & $\begin{array}{l}\text { Blackish brown peat. } \\
\text { Charcoal fragments }\end{array}$ & $\mathrm{H} 7$ & Sapric \\
\hline $86-94$ & Brown to dark brown peat & $\mathrm{H} 4$ & Hemic-Fibric \\
\hline $94-112$ & Dark brown peat & H5 & Hemic \\
\hline $112-120$ & $\begin{array}{l}\text { Dark brown peat. } \\
\text { Wood fragments }\end{array}$ & H6-7 & Sapric \\
\hline $120-160$ & $\begin{array}{l}\text { Reddish fibrous peat with } \\
\text { Sphagnum remains }\end{array}$ & $\mathrm{H} 2$ & Fibric \\
\hline $160-224$ & Grey-black peat & H7-8 & Sapric \\
\hline $224-232$ & $\begin{array}{l}\text { Grey-black peat with very } \\
\text { fine quartz sands } \\
\text { Minerogenic phase }\end{array}$ & H9 & Sapric \\
\hline
\end{tabular}

calculated by dividing the difference between the element content of each sample and the average value of the whole core by the standard deviation), which minimizes differences due to local effects (i.e. due to differences in the geological composition) and results in a relative scale of variation in enrichment to identify periods of elevated values.

In Teflon vessels an aliquot of $0.300 \mathrm{~g}$ of each sample was digested $\left(180{ }^{\circ} \mathrm{C}-5-1000 \mathrm{~W}\right.$ and $180^{\circ} \mathrm{C}-10$ $1000 \mathrm{~W}$ ) by microwave (Milestone, Ethos 1 plus) using a mixture of $8 \mathrm{~mL} 69 \% \mathrm{HNO}_{3}$ (PlasmaPURE-Scp Science) and $2 \mathrm{~mL}$ of $48 \% \mathrm{HF}$ (Sigma Aldrich). Due to the high organic matter content, the addition of $\mathrm{H}_{2} \mathrm{O}_{2}$ was also required. Then, the digested sample

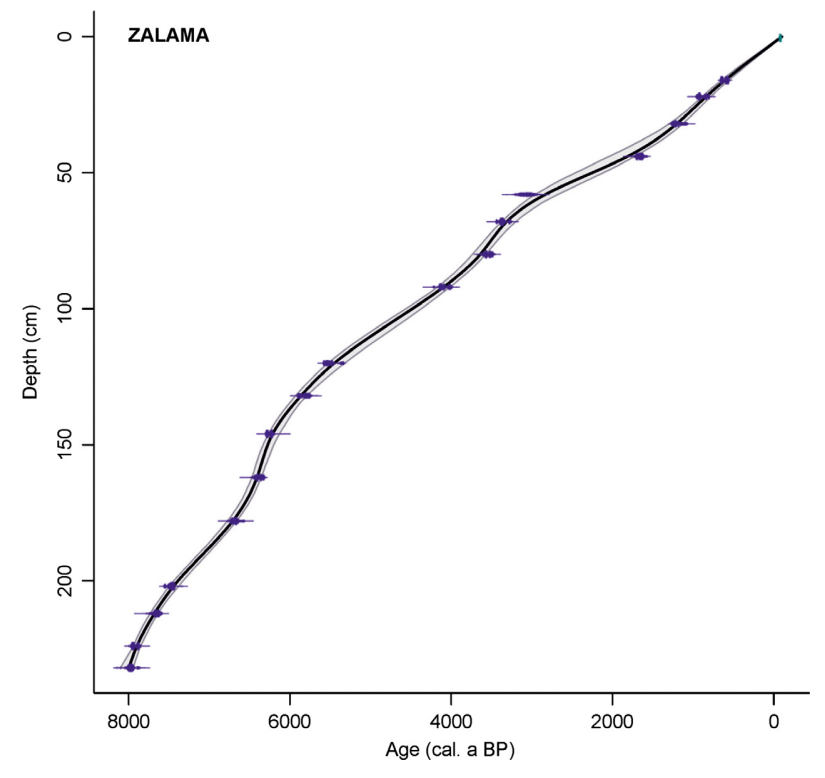

Fig. 2. Age-depth model of Zalama peat bog.

was flushed in a final volume of $25 \mathrm{~mL}$ with $2.5 \%$ $\mathrm{H}_{3} \mathrm{BO}_{3}$ (Sigma Aldrich). The sample was filtered and stored in plastic tubes in the cold and dark until analysed by quadrupole inductively coupled plasma-mass emission spectrometry (ICP-MS) using a Varian 820MS. Ten per cent of the samples were analysed in duplicate. All calibration standards were prepared as samples from multi-element solutions. For both elements, the correlation coefficients of the calibration lines were equal to or greater than 0.999. All measured elements were above the detection limits, whereas the blank sample values were below. To assess the precision and accuracy of analytical procedures and to check the calibration, we used five internationally certified reference materials (CRMs). Element recoveries

Table 2. AMS-radiocarbon data with $2 \sigma$ range of calibration from Zalama peat bog.

\begin{tabular}{|c|c|c|c|c|c|c|}
\hline Sample & Material & Depth interval $(\mathrm{cm})$ & Lab. code & Age $\left({ }^{14} \mathrm{C}\right.$ a BP $)$ & Age range $\left({ }^{14} \mathrm{C}\right.$ cal. a $\left.\mathrm{BP}\right)$ & $\begin{array}{l}\text { Calendar age a BP; } \\
\text { average probability }\end{array}$ \\
\hline ZAL 10 & Peat & $15-16$ & CNA626 & $635 \pm 30$ & $553-665$ & 599 \\
\hline ZAL 16 & Peat & $21-22$ & CNA627 & $990 \pm 40$ & $796-963$ & 902 \\
\hline ZAL 26 & Peat & $31-32$ & $\mathrm{Ua}-41646$ & $1245 \pm 34$ & $1073-1272$ & 1199 \\
\hline ZAL 34 & Peat & $42-44$ & CNA628 & $1755 \pm 30$ & $1565-1736$ & 1661 \\
\hline ZAL 41 & Peat & $56-58$ & CNA629 & $2920 \pm 50$ & $2925-3212$ & 3065 \\
\hline ZAL 46 & Peat & $66-68$ & Ua-41647 & $3142 \pm 34$ & $3324-3447$ & 3368 \\
\hline ZAL 52 & Peat & $78-80$ & Ua-41648 & $3321 \pm 31$ & $3475-3633$ & 3548 \\
\hline ZAL 58 & Peat & $90-92$ & CNA630 & $3740 \pm 30$ & $3984-4157$ & 4097 \\
\hline ZAL 72 & Peat & $118-120$ & Ua-41650 & $4757 \pm 41$ & $5328-5589$ & 5511 \\
\hline ZAL 78 & Peat & $130-132$ & Ua-41651 & $5076 \pm 40$ & $5734-5914$ & 5817 \\
\hline ZAL 85 & Peat & $144-146$ & Ua-41652 & $5454 \pm 38$ & $6190-6306$ & 6251 \\
\hline ZAL 93 & Peat & $160-162$ & CNA631 & $5615 \pm 35$ & 6309-6466 & 6387 \\
\hline ZAL 101 & Peat & $176-178$ & Ua-41653 & $5858 \pm 38$ & $6597-6753$ & 6680 \\
\hline ZAL 113 & Peat & $200-202$ & Ua-41654 & $6561 \pm 47$ & $7420-7566$ & 7470 \\
\hline ZAL 118 & Peat & $210-212$ & Ua-41655 & $6826 \pm 47$ & $7582-7750$ & 7658 \\
\hline ZAL 124 & Peat & $222-224$ & CNA632 & $7095 \pm 35$ & $7846-7981$ & 7932 \\
\hline ZAL 128 & Peat & $230-232$ & Ua-35895 & $7150 \pm 50$ & $7852-8053$ & 7973 \\
\hline
\end{tabular}




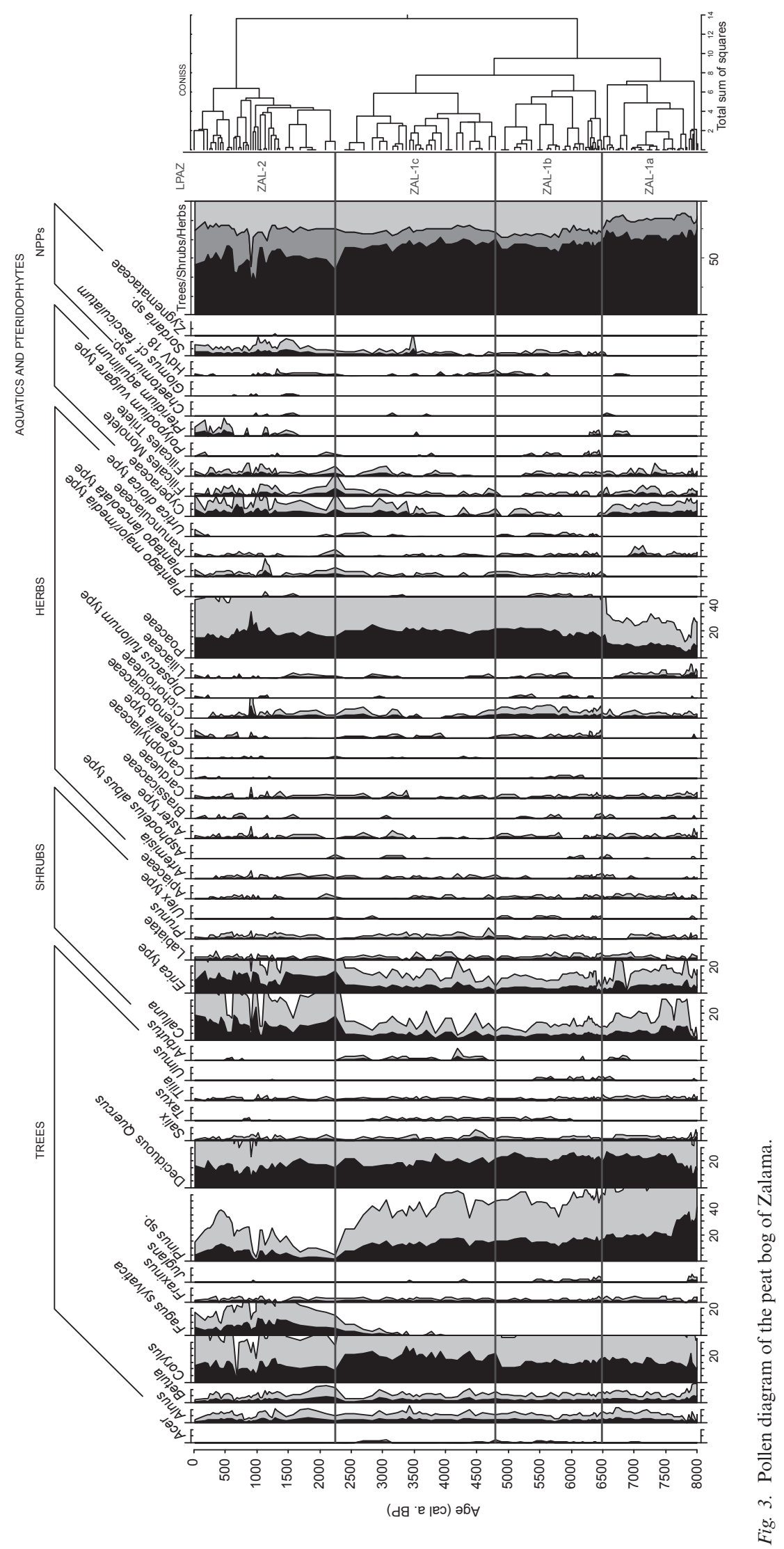


Table 3. V and Ti values from the peat bog of Zalama.

\begin{tabular}{|c|c|c|c|c|c|}
\hline \multirow[b]{2}{*}{ Certificated Reference Material } & \multirow[b]{2}{*}{$\mathrm{N}$} & \multicolumn{2}{|c|}{$\mathrm{V}\left(\mathrm{mg} \mathrm{kg}^{-1}\right)$} & \multicolumn{2}{|c|}{$\operatorname{Ti}(\%)$} \\
\hline & & Certified & Measured & Certified & Measured \\
\hline NIST - Montana Soil (2710a) & 3 & $82 \pm 9^{1}$ & $86 \pm 3$ & $0.311 \pm 0.007$ & $0.307 \pm 0.053$ \\
\hline NIST - Coal Fly Ash (1633c) & 3 & $286.2 \pm 7.9$ & $283 \pm 5.4$ & $0.724 \pm 0.030$ & $0.726 \pm 0.0410$ \\
\hline NIST - Coal (1632b) & 3 & $14^{1}$ & $17 \pm 1.5$ & $0.045 \pm 0.002$ & $0.043 \pm 0.012$ \\
\hline NIST - Apple Leaves (1515) & 3 & $0.26 \pm 0.03$ & $0.25 \pm 0.08$ & - & _- \\
\hline NIST - Peach Leaves (1547) & 3 & $0.37 \pm 0.03$ & $0.39 \pm 0.09$ & - & - \\
\hline
\end{tabular}

Reference value.

in CRMs were consistent with the certified values (Table 3). CRMs and blanks were inserted into every sample batch.

\section{Results}

\section{Pollen zonation}

The pollen diagram was divided into two main LPAZs (Fig. 3) using CONISS. The subzone ZAL-1 was in turn divided into three subzones (ZAL-1a, ZAL-1b and ZAL-1c). The diagram provides insight into the vegetation history of the Basque-Cantabrian Mountains from 8000 cal. a BP to the present, both at the local and regional scale.

Zone ZAL-1a (231-166 cm depth, 7975-6463 cal. a $B P)$. - The oldest section of this LPAZ (231$208 \mathrm{~cm}, 7975-7585 \mathrm{cal}$. a BP) shows that the main arboreal taxon was Pinus (44-34\%). Other taxa such as deciduous Quercus and Corylus have a secondary role $(<20 \%)$. Juglans is present with values $<5 \%$. Shrubs reached noteworthy values, mainly Erica and Calluna. Poaceae registered the lowest values in the entire sequence $(<10 \%)$. Hygrophilous taxa reached $5-8 \%$ of the total pollen. The rest of this LPAZ (208-166 cm, 7585-6463 cal. a BP) was characterized by the decline of pines, which decreased to 22\%. Deciduous Quercus and Corylus percentages rose to 27 and 19\%, respectively. Both shrubs (Erica and Calluna) and hygrophilous taxa (Cyperaceae, monolete and trilete ferns) were substantially represented.

Zone ZAL-1b (166-106 cm, 6463-4789 cal. a BP). This LPAZ showed lower values for tree pollen $(<65 \%)$, with mesophilous taxa as the main components. Deciduous Quercus exceeded 26\%, with Corylus in a secondary position (maximum values of $18 \%$ ). Pinus decreased (13-18\%) and Juglans reappeared. Taxus appeared at this LPAZ with very low values. Shrub percentages declined, with Erica and Calluna as the main taxa. Herbs increased markedly (maximum values of $32 \%$ ), with Poaceae as the main taxon (22\%). This area is also characterized by higher percentages of
Cardueae, Chenopodiaceae, Dipsacus fullonum, Plantago major/media, P. lanceolata and Urtica dioica, but with low values $(<2 \%)$. Sordaria reached maximum values of $2 \%$. Hygrophilous taxa showed lower values, almost all Cyperaceae.

Zone ZAL-1c (106-50 cm, 4789-2251 cal. a BP).-This zone had increasing values of tree pollen, reaching 68\%, the main contributor being Corylus $(27 \%)$. Other mesophilous taxa that maintained a continuous and significant presence were deciduous Quercus (16-25\%). In this LPAZ, Fagus occurred for the first time in the succession, at $3900 \mathrm{cal}$. a BP. Pine-pollen percentages exhibited a decreasing trend. Amongst the shrubs, Erica and Calluna were best represented. Herbs displayed a significant presence (21-31\%), with Poaceae as the main taxon (maximum 25\%). Cichorioideae and Fabaceae also displayed an increasing trend. From 4000 cal. a BP, Cyperaceae and monolete and trilete ferns showed an increasing trend. Amongst non-pollen palynomorphs, Sordaria reached a maximum peak of $5.2 \%$ at 3460 cal. a BP.

Zone ZAL-2 (50-0 cm, 2251-0 cal. a BP). - The diagram reflects several noteworthy changes in this LPAZ. Regarding tree pollen, this zone is characterized by increasing values of Fagus. At the beginning, its trend was upwards, and it reached high percentages $(13 \%)$. However, from 900 cal. a BP its values began to decline. Here, Corylus and deciduous Quercus maintained a noteworthy presence. The shrubs showed significant growth, Calluna and Erica increasing to reach their maximum percentages in the entire succession ( 25 and 19\%, respectively). Amongst the herbs, Poaceae continued as the main taxon, with the rest of the taxa

Table 4. Inorganic ash (\%), titanium and vanadium $\left(\mathrm{mg} \mathrm{kg}^{-1}\right)$ content in Zalama bog.

\begin{tabular}{lcrlr}
\hline & Average & SD & Min. & Max. \\
\hline Ash & 4.60 & 5.55 & 0.80 & 42.46 \\
$\mathrm{Ti}$ & 38.98 & 31.64 & 6.90 & 157.17 \\
$\mathrm{~V}$ & 2.30 & 1.98 & 0.17 & 11.37 \\
\hline
\end{tabular}




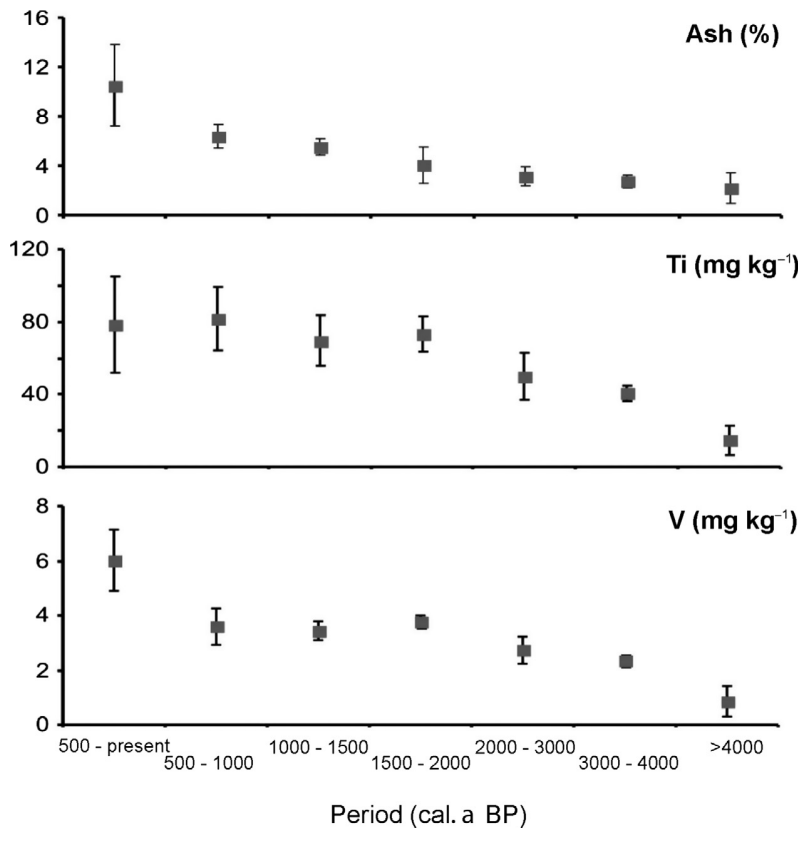

Fig. 4. Trends of atmospheric soil dust geoindicators in different periods of the development of Zalama bog. Periods: 1000 to $500 \mathrm{cal}$. a BP (Late Middle Ages); 1500 to 1000 cal. a BP (Early Middle Ages); 2000 to 1500 cal. a BP (Late Antiquity and Roman times); 3000 to 2000 cal. a BP (Late Bronze-Iron Age); 4000 to 3000 cal. a BP (Bronze Age).

registering values of $<3 \%$. Hygrophilous taxa increased their values. The main non-pollen palynomorph was Sordaria $(4.5 \%)$.

\section{Geochemical record}

The mean, standard deviation, and maximum and minimum concentrations of $\mathrm{Ti}$ and $\mathrm{V}$ and ash content are summarized in Table 4 . The values found were comparable to those found in bogs throughout Europe (Shotyk et al. 2002; Coggins et al. 2006; Cloy et al. 2011; Allan et al. 2013; Pontevedra-Pombal et al. 2013). Ti and V concentrations were significantly correlated $(r=0.948 ; p<0.0001 ; N=129)$, and both closely followed the ash content $(r=0.837$ and 0.828 respectively; $p<0.001 ; N=129$ ), suggesting that the inorganic content of the peats was supplied by atmospheric soil dust. The ash content and concentrations of lithogenic elements ( $\mathrm{Ti}$ and $\mathrm{V}$ ) showed a similar trend (Fig. 4) during bog development. Background values were not exceeded until after 4000 cal. a BP. From then on, the three geoindicators gradually increased until the present. The greater increase detected in the last 500 years is attributable to greater soil erosion resulting from agricultural and industrial intensification or to climatic changes over the last millennium (Le Roux et al. 2004; Zaccone et al. 2008; Pontevedra-Pombal et al. 2012).

\section{Discussion}

Pines vs. deciduous forests in the Basque-Cantabrian Mountains (8000-6500 cal. a BP)

The oldest part of the Zalama pollen record shows the highest values of pine pollen of the entire succession, reaching a maximum of $44 \%$ (Fig. 3). These values are not sufficient to support the presence of large pine forests in the local environment of the site. It is known that most pines, due to high pollen production and good dispersal ability, have a larger pollen-dispersal area than do other tree species (Poska \& Pidek 2010). According to studies of modern pollen rain in some well-developed pine forests, composed mainly of Pinus sylvestris, we infer the presence of large pine forests only when the values reach 60\% (López-Sáez et al. 2013). Accordingly, we suggest at this time the presence of regional pine forests, or perhaps the presence of scattered trees near the site, but in any case mature forests. The significance of our data is that they indicate the presence of pine forests in the study area during the middle Holocene, although these forests do not have a phytosociological characterization in the literature of northern Spain (Rivas-Martínez 1987). One compelling question is what species of pines were present in the environment in the last eight millennia. Although we could not distinguish between them and we retrieved no macro-remains, we suggest that the vast majority of pine pollen in the core originated from Pinus sylvestris because it is the only species remaining today in the area surrounding the peat bog (Aseginolaza et al. 1996). In this area, the 19th-century authors Willkomm \& Lange (1861), following the works of Planelles (1852) and Olazabal (1856), suggested the nature of relict Scots pine forests in the Cantabrian Mountains (Rubiales et al. 2010, 2012). Similarly, CatónSantaren \& Uribe-Etxebarria (1980), Ruiz-Urrestarazu (1989) and Aseginolaza et al. (1996) pointed to the presence of relict Pinus sylvestris forests in the Basque Country, hardly altered by anthropogenic activities in the last millennium. However, we cannot completely rule out the contribution of other pines, such as Pinus nigra, macrofossils of which have been found in several deposits of the northern plateau (García-Amorena et al. 2011).

According to the data from the Zalama peat bog, from 7585 cal. a BP, pines suffered a major setback parallel to the development of deciduous forests in the Basque-Cantabrian Mountains. The reasons for this phenomenon are probably climatic. The increased precipitation and temperature in the early middle Holocene, as detected in lake, bog, marine sediment and speleothem records in the northern Iberian Peninsula (Santos et al. 2000; Roucoux et al. 2001; Moreno et al. 2011; Stoll et al. 2013), which resulted in tree recolonization, caused an early decline of pine forests across 
the northern Iberian Peninsula. This phenomenon was sharper and more sudden in the Atlantic areas of northern Iberia, as demonstrated by Muñoz-Sobrino (2001), Muñoz-Sobrino et al. (2007) and Rubiales et al. (2008, 2011, 2012). Deciduous taxa, especially Quercus, Corylus and sometimes Betula, in this temperate and humid climate had certain advantages that allowed them to compete successfully against coniferous formations, which survived in other areas. Pines therefore remained in such regions as the more continental, dry inland areas of the southern slopes of the Cantabrian Range, less suitable for the competition of hardwoods (Muñoz-Sobrino 2001; Rubiales et al. 2008, 2011; Jalut et al. 2010; Muñoz-Sobrino et al. 2012). From these times, c. 7585 cal. a BP, deciduous trees formed the dominant forests in the environs of the Zalama bog. Above all, hazel and deciduous Quercus started to play a major role in local forests. Deciduous Quercus had already gained terrain since the decline of pines, and became one of the dominant Holocene forest taxa. Hazel was also a foremost species in the wet mesophylous forest of the northern Iberian Peninsula, where it formed part of mixed deciduous formations.

Notably, Juglans also expanded its presence at this time. It was documented at the beginning of the sequence (ZAL-1), but between 6460 and 5500 cal. a BP (lower part of ZAL-1b) it became more abundant, although still with low values $(<2 \%)$. Walnut has usually been considered to have been introduced into in Western Europe during the late Holocene (Beug 1975), but research in the last few decades has provided sufficient data to demonstrate its indigenous nature in the Iberian Peninsula (Sánchez-Goñi 1988; Carrión \& Sánchez 1992; Ramil-Rego et al. 2000; Da Silva-Oliveira 2012; Mercuri et al. 2013), as in the case of the Zalama pollen record. In addition, some development of riparian communities (Alnus, Fraxinus and Salix) can be detected in the diagram, probably at a regional scale. This, together with the increase in fern spores (monolete and trilete) and Ranunculaceae, confirms the onset of more humid conditions in this period. This pattern is not an isolated event but a regional trend, involving the entire Atlantic area of northern Spain, as has been demonstrated in other deposits, such as the Los Tornos (Peñalba 1989) and Pozo do Carballal (Muñoz-Sobrino et al. 1997) peat-bog pollen records. A multi-proxy climatic reconstruction for Enol Lake suggests favourable temperatures and the presence of highly stable forested landscapes at $8700-4650 \mathrm{cal}$ a. BP (Moreno et al. 2011).

\section{First anthropogenic evidence (c. 6500-3300 cal. a BP)}

In addition to the regression of pines and the progressive advance of deciduous forests, other changes in the landscape were detected by $6500 \mathrm{cal}$. a BP in the
Zalama pollen record. The most notable are related to the first evidence of human impact c. 6460 cal. a BP. From then on, the pollen diagram reflects some decrease in forests and their replacement by open areas, mainly pastures of Poaceae and other synanthropic taxa (Plantago lanceolata, P. major/media, Urtica dioica, Caryophyllaceae, Chenopodiaceae and Cichorioideae; Fig. 3). These elements, together with the contemporaneous appearance of coprophilous fungi (Sordaria), suggest nearby pastures and pastoral pressure (Behre 1981; Sjögren 2006; López-Sáez \& López-Merino 2007; Sjögren \& Lamentowicz 2008). In addition, the presence of pyrophilous taxa (Asphodelus albus) and carbonicolous fungi (Chaetomium sp.) appears to reflect the use of fire as a tool for opening spaces by early farming communities (van Geel 1978; Kuhry 1985).

These first pieces of evidence of human impact on forests are related to early cattle raising in the BasqueCantabrian Mountains. The northern area of the Iberian Peninsula in general and the Basque-Cantabrian Mountains in particular, have been considered marginal areas for Neolithic farming (Zapata \& Peña-Chocarro 2013). However, in the last decade several archaeological findings, supported mainly by archaeobotanical research, have refuted these assumptions (Zapata 2002; Zapata et al. 2004). In fact, such evidence can be explained by the profusion in the region of archaeological sites precisely dated to the Early Neolithic (end of the 8th and first half of 7th millennia ago) such as Los Canes, Los Gitanos, El Mirón, Kobaederra, Pico Ramos, Lumentxa, Arenaza, Herriko Barra and Marizulo (Zapata et al. 1997, 2007; Alday \& Mujika 1999; Arias \& Altuna 1999; Zapata 2002; Iriarte et al. 2004; Arias 2005; Peña-Chocarro et al. 2005; Ontañón et al. 2013). This phenomenon of increased human impact is also detected in the pollen records of the nearby Monte Areo (López-Merino et al. 2010) and Pena Veira peat bogs (Ramil-Rego \& Aira 1993). This intensity of human impact (forest clearance and burning) 6500 years ago has also been recorded in other regions of northern Spain such as Galicia, by clear signs of erosion, cumulic soil formation and the appearance of stone and charcoal lines (Kaal et al. 2008).

This anthropogenic evidence indicates some reduction in human activity in the Zalama peat bog between 4800 and 3400 cal. a BP, this being manifested in the interruption of continuous curves of different taxa such as Sordaria, Urtica dioica, Plantago lanceolata, Dipsacus fullonum, Cichorioideae, Chenopodiaceae and Aster (Fig. 3). This phase of less human pressure during the Copper and Early Bronze Ages is also reflected by the expansion of hazel, which prospered because of its pioneering nature (Costa-Tenorio et al. 2005), and occupied certain areas previously devoted to pasture. This episode is part of a long-term climatic 
Table 5. Chronology of the expansion of Fagus in northern Iberia.

\begin{tabular}{llcll}
\hline Region & Site & Altitude (m a.s.l.) & Date of the expansion of Fagus & References \\
\hline \multirow{2}{*}{ Western Pyrenees } & Occabe & 1300 & c. 4500 cal. a BP & Cugny (2011) \\
& Artxilondo & 1100 & c. 4500 cal. a BP & Galop et al. (2004) \\
& Atxuri & 500 & c. 4200 cal. a BP & Peñalba (1989); Pérez-Díaz et al. (2015) \\
& Quinto Real & 910 & c. 4000 cal. a BP & Galop et al. (2004) \\
& Belate & 847 & After 3335-2955 cal. a BP & Peñalba (1989) \\
Basque-Cantabrian & Saldropo & 625 & c. $4150-3645$ cal. a BP & Peñalba (1989) \\
Mountains & Los Tornos & 920 & After 2965-2715 cal. a BP & Muñoz-Sobrino et al. (2005) \\
& Zalama & 1330 & c. $3300-3000$ cal. a BP & This study \\
Cantabrian Region & Cueto de la Avellanosa & 1320 & c. 3000 cal. a BP & Mariscal (1983) \\
& Enol Lake & 1070 & c. 3500 cal. a BP & Moreno et al. (2011) \\
& Lago de Ajo & 1570 & c. 3200 cal. a BP & Allen et al. (1996) \\
\hline
\end{tabular}

phase of global cooling (Magny \& Haas 2004), which has also been recorded in the northwestern Iberian Peninsula (Fábregas et al. 2003).

Another noteworthy phenomenon during this time is the beginning of the continuous curve of Taxus. This plant was not identified previously, but c. 6000 cal. a BP it makes its appearance in the Zalama pollen record with a continuous curve until 3000 cal. a BP. Its presence is not prominent $(<2 \%)$ but its appearance at this time is remarkable. Although it is an anemophilous tree, its pollen production and dispersal rate are very low. Some studies show a meagre representation in surface samples taken near the tree, reflecting that even extremely low pollen values $(1-2 \%)$ must attest to the local presence of this genus (Heim 1970; Noryskiewicz 2003). The increase in the use of yew wood is detected at some archaeological sites located in northern Iberia dated to the Early Neolithic, such as El Mirón, Aizpea and other archaeological sites in the Sierra de Cantabria (Zapata 2001, 2012; Ruiz-Alonso 2014). However, from the charcoal record alone it is difficult to determine the real significance of Taxus in the landscape. Indeed previous studies have shown that wood macro-remains linked to human settlements can be used only as indicators of the presence of this genus, rather than as a quantitative estimate of the prevalence of Taxus in the landscape (Pérez-Díaz et al. 2013; Uzquiano et al. 2014). From 6000 cal. a BP the first continuous curves of yew pollen are recorded in many deposits located in the northern Iberian Peninsula, particularly in some well-dated peat bogs such as Zalama and the nearby Los Tornos in the BasqueCantabrian Mountains as well as in other pre-Pyrenean bogs such as Atxuri and Belate (Peñalba 1989; Pérez-Díaz et al. 2015). They all have continuous pollen values spanning a quite similar chronology, between 6000 and $2700 \mathrm{cal}$. a BP. In another pollen record, Saldropo (Peñalba 1989, 1994), no continuous values were recorded, but rather only isolated occurrences $5000-2750$ cal. a BP.

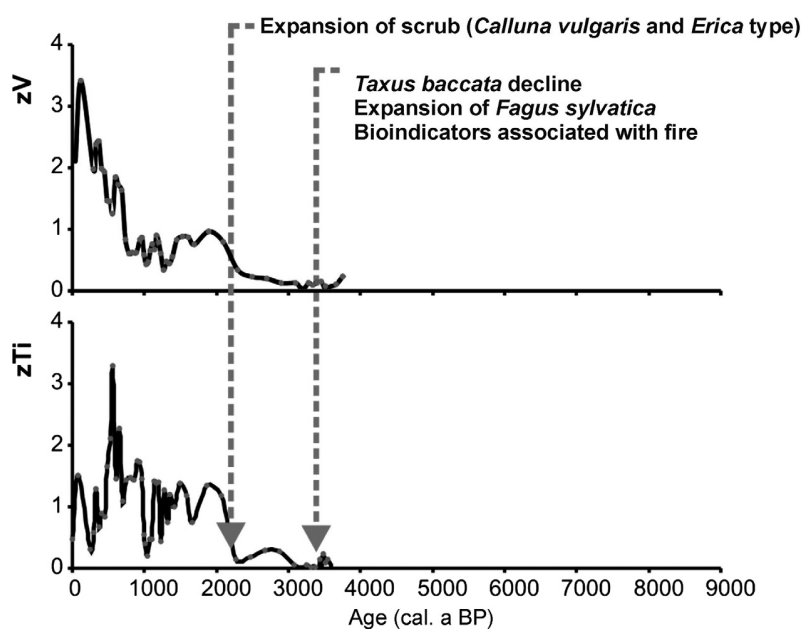

Fig. 5. Distribution of $\mathrm{Ti}$ and $\mathrm{V}$ trace elements over time and the main changes in the vegetal landscape in the late Holocene record of Zalama peat bog.

The expansion of Fagus and the current landscape status (3300 cal. a BP-present day)

In this last phase, the forests in this area underwent a major change, a transformation led by the expansion of a single taxon: Fagus. Its first appearance in the Zalama pollen record was dated to $3900 \mathrm{cal}$. a BP with sporadic, discontinuous and low values. However, from 3300 cal. a BP the pollen diagram shows the presence of a continuous curve of this new element, and from 3000 cal. a BP its values exceed $1 \%$, reaching a maximum of $13 \%$ (Fig. 3). Therefore, beech forests were one of the main vegetation communities in the late Holocene of the Basque-Cantabrian Mountains and nearby regions such as the western Pyrenees and Cantabrian Region (Table 5).

It is currently accepted that the present Iberian beech forests originated from populations located in several refuge areas, according to the growing number of palaeobotanical finds in ancient chronologies and genetic studies (Martínez-Atienza \& Morla-Juaristi 
1992; Rodríguez-Guitián et al. 1996; Ramil-Rego et al. 2000; Costa-Tenorio et al. 2005; Magri et al. 2006; López-Merino et al. 2008; Magri 2008). From those regions, located mainly in the northern Iberian Peninsula, Fagus expanded during the late Holocene. The causes of the expansion of beech can be summarized by two main non-mutually exclusive factors: climatic and anthropogenic forcing (Galop et al. 2004; Bradshaw \& Lindbladh 2005; Tinner \& Lotter 2006; Giesecke et al. 2007; López-Merino et al. 2008; Magri 2008; Valsecchi et al. 2008; Muñoz-Sobrino et al. 2009; Bradshaw et al. 2010; Bradley et al. 2013).

Regarding the prevailing climate conditions in this area, the palynological record of Zalama indicate some increase in effective moisture by the rising values of Corylus and fern spores since 3300 cal. a BP. Similarly, other regional studies, such as the multi-proxy analysis of the Enol Lake mentioned above, suggest a wetter climate with more humid conditions between 4650 and 2200 cal. a BP (Moreno et al. 2011). Such conditions would be optimal for Fagus development.

The other agent perhaps involved in this process, human disturbance, caused open landscapes as a result of agropastoral activities, which could have favoured Fagus regeneration (Iversen 1973; Watts 1973; Björkman 1999). This would have allowed them to form mixed forests with other deciduous tree formations, and later monospecific beech forests.

In the succession of Zalama, from 3400 cal. a BP (Middle Bronze Age), the pollen diagram shows renewed anthropization, after a certain abandonment phase mentioned above (4800-3400 cal. a BP). This is manifested by some intensification in local pastoral activities and some indicators of disturbance associated with fire and overgrazing (Chaetomium sp. and Asphodelus albus). This phase coincides with lithogenic elements surpassing, for the first time in the Zalama record, their background levels, as represented by their z-scores (Fig. 5), indicating greater soil erosion. Passing this first buffering threshold may be an indirect sign of the aforementioned deforestation, but also of the intensity of the direct impact of the increased use of soil resources, coinciding with the more abundant cereal pollen and coprophilous fungi spores (Fig. 3). The beginning of these erosive crises has been detected in soils, peatlands and archaeological sites around the northwestern Iberian Peninsula (Fábregas et al. 2003). In theZalama bog, the ash content and V and Ti concentrations began to increase before any remarkable sign of forest decline. This characteristic has also been detected in other studies, suggesting that lithogenic geoindicators are more sensitive to small changes in the landscape than pollen is (Hölzer \& Hölzer 1998; Martínez-Cortizas et al. 2005). This phenomenon of increasing anthropization by $3400 \mathrm{cal}$. a BP occurred at the same time as the start of the continuous curve of Fagus (Fig. 3). Thus it seems probable that the expan- sion of beech was favoured by anthropogenic disturbances, as seen in other parts of Europe such as the French Pyrenees (Galop \& Jalut 1994; Jalut et al. 1998) or even within the Iberian Peninsula (RamilRego et al. 2000; Martínez-Cortizas et al. 2005; López-Merino et al. 2008). The emergence of beech in the vegetation of the Basque-Cantabrian Mountains significantly affected the existing forest communities. The mixed deciduous forests dominated by Quercus and Corylus suffered a significant setback at this time because of the great competitive ability of beech in disturbed environments.

The emergence of Fagus coincides also with the decline of Taxus c. 3000-2700 cal. a BP. This decline does not appear to be due to a single factor but rather to the co-occurrence of different elements, both natural and human, which encouraged these regressive dynamics in the late Holocene. Amongst the major causes, several biological, environmental and anthropic factors can be noted: e.g. increasing anthropic pressure, competition with other tree species (mostly Fagus) and selfregeneration problems (Iszkulo 2010; Linares 2013). Other taxa harmed by the expansion of beech were the conifers. Pines, which displayed a regressive trend throughout the Holocene (García-Antón et al. 1997), also suffered a significant setback at that time, and almost disappeared from the pollen record of the Zalama peat bog (Fig. 3).

In addition to the beech forest formations, other elements now played a major role at a local scale, i.e. shrubs. From 2250 cal. a BP these thickets showed an increasing trend, with a greater representation of $\mathrm{Cal}$ luna vulgaris and Erica. This coincidence with other notable evidence of human impact (some deforestation, anthropogenic taxa and grasslands) may indicate that this expansion of shrubs must be originated by the perturbations derived from the extension of grazing areas related to the expanding use of this pastoral setting. In the Zalama bog, this phase of retreat in trees, expansion of Fagus and shrubs, and in general, anthropization of the landscape is synchronous with a dramatic increase in ASD deposition (Fig. 5), which marks the beginning of intensifying soil erosion. Besides consistency with biotic markers of agriculture and grazing, this erosive phase was also coeval with the onset of iron metallurgy in the Cantabrian-Pyrenean area, the development of which led to extensive deforestation (Etxezarraga 2004). The same erosive phase was recorded in polycyclic soils and peatlands in northwest Iberia, including by dense lines of charcoal, gravel and stones, and growing palaeopollution (van Mourik 1986; Martínez-Cortizas et al. 2005; CostaCasais et al. 2009; Pontevedra-Pombal et al. 2013; Silva-Sánchez et al. 2014). These shrublands have dominated the landscape at a local scale until the present in our study area. The main components of the landscape near the bog are currently Calluna vulgaris 
and Erica tetralix. This phenomenon of heathland expansion is commonplace in the northwestern Iberian Peninsula for this period (e.g. Allen et al. 1996; Muñoz-Sobrino et al. 1997; Muñoz-Sobrino 2001; Morales-Molino et al. 2011, 2013; Morales-Molino \& García-Antón 2014).

\section{Conclusions}

The study of the raised ombrotrophic bog of Zalama contributes to the knowledge of the evolution of the landscape in the northern Iberian Peninsula during the Holocene. The bog's location on the border between the Eurosiberian and Mediterranean regions offers an added value, reflecting the history of vegetation dynamics, climatic conditions and anthropogenic activities in a region of special biogeographical interest.

The beginning of the succession $(8000$ cal. a BP) is characterized by pine forests, showing the importance of pine woods in the southwestern European landscape in the early middle Holocene. The climatic conditions, more humid and temperate, triggered the retreat of Pinus sylvestris from this area, dated in Zalama from $7600 \mathrm{cal}$. a BP. In this context, rising temperatures and greater precipitation favoured the development of deciduous forest (oak, hazel, birch), much better adapted to the new conditions. Since then, pines have been restricted to the more continental and drier areas on the southern slopes of the area.

Palaeobotanical data show that yew has been present in several places in the northern Iberian Peninsula since at least the Pleistocene. However, higher values are documented during the middle Holocene. From 8000 cal. a BP, significant use of yew wood appears in archaeological contexts. From 6000 cal. a BP, yew expands somewhat, according to its increasing presence in the pollen records. This phase lasted several millennia, until the late Holocene, when yew populations underwent a regression around $3000 \mathrm{cal}$. a BP.

The first anthropogenic disturbances are noted in the area of the Zalama peat bog during the middle Holocene. From 6460 cal. a BP, pasturelands increasingly occupy some open areas in this mountain range. The presence of anthropogenic taxa and coprophilous fungi points to the new productive economic activities related to the first crop raising and animal husbandry in the Basque-Cantabrian Mountains.

In the late Holocene the biggest change in the vegetal landscape was the expansion of beech forests. The spread of beech forests in Zalama is documented from 3300 cal. a BP, at a very similar time as in other areas of the northern Iberian Peninsula. Anthropogenic perturbations may have favoured this phenomenon.

The geochemical record of the Zalama bog suggests that the carrying capacity of the soil was definitely exceeded in the late Holocene, beginning a sequence of erosive phases contemporaneous with deforestation and the expansion of anthropic spaces and widespread shrublands.

Acknowledgements. - S. Pérez-Díaz is currently supported by a postdoctoral research grant (Basque Government) and is part of the Research Group in Prehistory IT622-13/UFI 11-09 of the University of the Basque Country (UPV/EHU) and Project HAR2011-23716 (Nuevos cultivos, nuevos paisajes), funded by the Plan Nacional I+D+I. Thanks are extended to Juan Carlos Nóvoa from the Soil Science and Agricultural Chemistry Group of the University of Vigo for invaluable help with the fieldwork, and to Patxi Heras and Marta Infante from the Natural History Museum of Álava for sharing with us their knowledge on peatlands of the Basque Country. We also want to thank the two anonymous reviewers for their constructive comments.

\section{References}

Aguirre-Pascual, E. 2011: Plan de gestión del LIC de Ordunte, 385 pp. Diputación Foral de Bizkaia, Bilbao.

Alday, A. \& Mujika, J. A. 1999: Nuevos datos de cronología absoluta concerniente al Holoceno Medio en el área vasca. El Mundo indígena (XXIV Congreso Nacional de Arqueología), 95-106. Instituto de Patrimonio Histórico, Murcia.

Allan, M., Le Roux, G., De Vleeschouwer, F., Bindler, R., Blaauw, M., Piotrowska, N., Sikorski, J. \& Fagel, N. 2013: High-resolution reconstruction of atmospheric deposition of trace metals and metalloids since AD 1400 recorded by ombrotrophic peat cores in Hautes-Fagnes, Belgium. Environmental Pollution 178, 381-394.

Allen, J. R. M., Huntley, B. \& Watts, W. A. 1996: The vegetation and climate of north-west Iberia over the last 14.000 yr. Journal of Quaternary Science 11, 125-147.

Arias, P. 2005: Determinaciones de isótopos estables en restos humanos de la Región Cantábrica. Aportación al estudio de la dieta de las poblaciones del Mesolítico y del Neolítico. Munibe (Antropologia-Arkeologia) (Homenaje a Jesús Altuna) 57, 359374.

Arias, P. \& Altuna, J. 1999: Nuevas dataciones absolutas para el Neolítico de la Cueva de Arenaza (Bizkaia). Munibe (Antropologia-Arkeologia) 51, 161-171.

Aseginolaza, C., Gómez, D., Lizaur, X., Monserrat, G., Morante, G., Salaverría, M. R. \& Uribe-Etxebarria, P. M. 1996: Vegetación de la Comunidad Autónoma del País Vasco. 362 pp. Gobierno Vasco, Vitoria-Gasteiz.

Barber, K. E. 1993: Peatlands as scientific archives of past biodiversity. Biodiversity and Conservation 2, 474-489.

Bariego, P. \& Gastón, A. 2002: Catálogo florístico de los Montes de Ordunte (Burgos, España). Ecología 16, 97-152.

Behre, K. E. 1981: The interpretation of anthropogenic indicators in pollen diagrams. Pollen et Spores 23, 225-245.

Beug, H. J. 1975: Man as a factor in the vegetational history of the Balkan Peninsula. In Jordanov, D., Bondev, I., Kozuharov, S. Kuzmanov, B. \& Palamarev, E. (eds.): Problems of Balkan Flora and Vegetation, 72-78. Proceedings of the First International Symposium on Balkan Flora and Vegetation, Varna, June 7-14, 1973. Publishing House of the Bulgarian Academy of Sciences, Sofia.

Björkman, L. 1999: The establishment of Fagus sylvatica at the stand-scale in southern Sweden. The Holocene 9, 237-245.

Blaauw, M. 2010: Methods and code for "classical" age-modelling of radiocarbon sequences. Quaternary Geochronology 5, 512-518.

Bradley, L. R., Giesecke, T., Hallsall, K. \& Bradshaw, R. H. W. 2013: Exploring the requirements for anthropogenic disturbance to assist the stand-scales expansion of Fagus sylvatica L. outside southern Scandinavia. The Holocene 23, 579-586.

Bradshaw, H. R. H., Kito, N. \& Giesecke, T. 2010: Factors influencing the Holocene history of Fagus. Forest Ecology and Management 259, 2204-2212.

Bradshaw, R. H. W. \& Lindbladh, M. 2005: Regional spread and stand-scale establishment of Fagus sylvatica and Picea abies in Scandinavia. Ecology 86, 1679-1686. 
Carrión, J. S. \& Sánchez, P. 1992: Palynological data in support of the survival of walnut (Juglans regia L.) in the western Mediterranean area during last glacial times. Journal of Biogeography 19, 623-630.

Catón-Santaren, B. \& Uribe-Etxebarria, P. M. 1980: Mapa de vegetación de Álava, 69 pp. Diputación Foral de Álava, Vitoria-Gasteiz.

Chambers, F. M., Daniell, J. R. G. \& ACCROTELM Members 2010: Peatland archives of late-Holocene climate change in northern Europe. Pages 18, 4-6.

Cloy, J. M., Farmer, J. G., Graham, M. C. \& MacKenzie, A. B. 2011: Scottish peat bog records of atmospheric vanadium deposition over the past 150 years: comparison with other records and emission trends. Journal of Environmental Monitoring 13, 58-65.

Coggins, A. M., Jennings, S. G. \& Ebinghaus, R. 2006: Accumulation rates of the heavy metals lead, mercury and cadmium in ombrotrophic peatlands in the west of Ireland. Atmospheric Environment 40,260-278.

Costa-Casais, M., Martínez-Cortizas, A., Pontevedra-Pombal, X. \& Criado-Boado, F. 2009: Analysis of landforms in geoarchaeology: Campo Lameiro, NW Iberian Peninsula. Memoria Descriptiva della Carta Geologica d'Italia LXXXVII, 39-51.

Costa-Tenorio, M., Morla-Juaristi, C. \& Sainz-Ollero, H. 2005: Los bosques ibéricos. Una interpretación geobotánica, 598 pp. Planeta, Barcelona.

Cugny, C. 2011: Apports des microfossiles non-polliniques à l'histoire du pastoralisme sur le versand nord pyréneén. Entre référentiels actuels et reconstitution du passé. Vol. 1. Texte et figures/Vol. 2. Illustrations et descriptions de microfossiles, Ph.D. thesis, University Toulouse II Le Mirail, $280 \mathrm{pp}$.

Da Silva-Oliveira, D. 2012: Vegetation response to Holocene climate variability in south-western Europe. Ph.D. thesis, Universidade de Lisboa, $121 \mathrm{pp}$.

Etxezarraga, I. 2004: Iron paleometallurgy in the Cantabric Basque Country: the haizeolak. A state of the art. Munibe 56, 87104.

EUSKALMET 2011: Tabla de parámetros meteorológicos. Available at: http://www.euskalmet.euskadi.net/s07-5853x/es/contenidos/info rmacion/cli_2013/es_clieus/adjuntos/capitulo03(2013).pdf (accessed 15.10.2014).

Fábregas, R., Martínez-Cortizas, A., Blanco-Chao, R. \& Chesworth, W. 2003: Environmental change and social dynamics in the second-third millennium BC in NW Iberia. Journal of Archaeological Science 30, 859-871.

Fægri, K. \& Iversen, J. 1989: Text-Book of Pollen Analysis, 328 pp. John Wiley \& Sons, Chichester.

Galop, D. \& Jalut, G. 1994: Differential human impact and vegetation history in two adjacent Pyrenean valleys in the Ariège basis, southern France, from $3000 \mathrm{BP}$ to present. Vegetation History and Archaeobotany 3, 225-244.

Galop, D., Carozza, L., Marembert, F. \& Bal, M. C., 2004: Activités agropastorales et climat durant l'Âge du Bronze dans les Pyrénées: L'état de la question à la lumière des donnes environnementales et archéologiques. In VVAA (eds.): Emprises et déprises agricoles, expansion et régression des sociétés entre 3500 et 2500 BP, 107-119. CHTS, Besançon.

García-Amorena, I., Rubiales, J. M., Moreno-Amat, E., IglesiasGonzález, R. \& Gómez-Manzaneque, F. 2011: New macrofossil evidence of Pinus nigra Arnold on the Northern Iberian Meseta during the Holocene. Review of Palaeobotany and Palynology 163, 281-288.

García-Antón, M., Franco-Múgica, F., Maldonado, J., Morla-Juaristi, C. \& Sainz, H. 1997: New data concerning the evolution of the vegetation in Lillo pinewood (Leon, Spain). Journal of Biogeography 26, 929-934.

Garrote, A., Muñoz, L., García, I. \& Eguiguren, E. 1992: Mapa Geológico del País Vasco. Hoja 60-III y 85-I (Zalama). Ente Vasco de la Energía. Departamento de Industria y Energía, Gobierno Vasco, Vitoria-Gasteiz.

van Geel, B. 1978: A palaeoecological study of Holocene peat bog sections in Germany and The Netherlands. Review of Palaeobotany and Palynology 25, 1-120. van Geel, B. 2001: Non-pollen palynomorphs. In Smol, J. P., Birks, H. J. B. \& Last, W. M. (eds.): Tracking Environmental Change using Lake Sediments; Vol. 3: Terrestrial, Algal and Silicaceous Indicators, 99-119. Kluwer Academic Publishers, Dordrecht.

van Geel, B. 2006: Fossil ascomycetes in Quaternary deposits. Nova Hedwigia 82, 313-329.

van Geel, B., Bohncke, S. J. P. \& Dee, H. 1981: A palaeoecological study of an Upper Late Glacial and Holocene sequence from 'De Borchert', The Netherlands. Review of Palaeobotany and Palynology $31,367-448$.

van Geel, B., Buurman, J., Brinkkemper, O., Schelvis, J., Aptroot, A., van Reenen, G. \& Hakbijl, T. 2003: Environmental reconstruction of a Roman Period settlement site in Uitgeest (The Netherlands), with special reference to coprophilous fungi. Journal of Archaeological Science 30, 873-883.

van Geel, B., Coope, G. R. \& van der Hammen, T. 1989: Palaeoecology and stratigraphy of the Lateglacial type section at Usselo (The Netherlands). Review of Palaeobotany and Palynology 60, 25-129.

Giesecke, T., Hickler, T., Kunkel, T., Sykes, M. T. \& Bradshaw, R. H. W. 2007: Towards an understanding of the Holocene distribution of Fagus sylvatica L. Journal of Biogeography 34, 118-131.

Girard, M. \& Renault-Miskovsky, J. 1969: Nouvelles techniques de préparation en palynologie appliquées à trois sédiments du Quaternaire final de l'Abri Cornille (Istres, Bouches du Rhône). Bulletin de l'Association Française pour l'Etude du Quaternaire 1969, 275-284.

Goeury, C. \& de Beaulieu, J. L. 1979: À propos de la concentration du pollen à l'aide de la liqueur de Tholet dans les sédiments minéraux. Pollen et Spores 21, 239-251.

Grimm, E. C. 1987: Coniss: a Fortran 77 program for stratigraphically constrained cluster analysis by the method of incremental sum of squares. Computers and Geosciences 13, 13-35.

Grimm, E. C. 1992: Tilia, version 2. Illinois State Museum, Research and Collection Center, Springfield, IL.

Grimm, E. C. 2004: TGView. Illinois State Museum, Springfield, IL.

Heim, J. 1970: Les relations entre les spectres polliniques récents et la végétation actuelle en Europe occidentale. Ph.D. thesis, Université de Louvain, $181 \mathrm{pp}$.

Heras, P. \& Infante, M. 2004: La turbera cobertor del Zalama (Burgos-Vizcaya): un enclave único en riesgo de desaparición. Estudios del Museo de Ciencias Naturales de Álava 18-19, 49-57.

Heras, P. \& Infante, M. 2005: More about windmills and blanket bogs. Zalama in Northern Spain. IMGC Newsletter 2005, 22.

Hölzer, A. \& Hölzer, A. 1998: Silicon and titanium in peat profiles as indicators of human impact. The Holocene 8, 685-696.

Iriarte, M. J. 1995: Análisis palinológico del monumento megalítico de La Boheriza 2 (Karrantza, Bizkaia). Kobie (Serie Paleoantropología) 22, 158-161.

Iriarte, M. J. 1999: Análisis palinológico del dolmen de La Cabaña 4 (Karrantza, Bizkaia). Isturitz 10, 242-245.

Iriarte, M. J. 2008: Vegetation landscape and the anthropization of the environment in the central sector of the Northern Iberian Peninsula: current status. Quaternary International 200, 66-76.

Iriarte, M. J. 2012: The vegetational context of El Mirón Cava throughout the Early to Middle Holocene. Contributions from palynological study. In Straus, L. G. \& González-Morales, M. R. (eds.): El Miron Cave. Cantabrian Spain. The Site and its Holocene Archaeological Record, 119-142. University of New Mexico, Albuquerque.

Iriarte, M. J., Mujika, J. A. \& Tarriño, A. 2004: Herriko Barra (Zarautz-Guipuzkoa): caractérisation industrielle et économique des premiers groupes de producteurs sur le littoral Basque. Actas del Colloque Unité et diversité des processus de néolithisation sur la façade atlantique de l'Europe, Bulletin de la Société Préhistorique Française XXXVI 127-136.

Iszkulo, G. 2010: Success and failure of endangered trees species: low temperatures and low light availability affect survival and growth of European yew (Taxus baccata L.) seedlings. Polish Journal of Ecology 58, 259-271.

Iversen, J. 1973: The development of Denmark's nature since the last glacial. Danmarks Geologiske Undersøgelse 7-C, 345-445. 
Jalut, G., Galop, D., Belet, J. M., Aubert, S., Esteban-Amat, A., Bouchette, A., Dedoubat, J. J. \& Fontugne, M. 1998: Histoire des forêts du versant nord des Pyrénées au cour de 30000 dernierès annes. Journal Bonanique de la Societé Botanique Française 5, 7384.

Jalut, G., Turu, V., Dedoubat, J. J., Otto, T., Ezquerra, J., Fontugne, M., Belet, J. M., Bonnet, L., García de Celis, A., Redondo-Vega, J. M., Vidal-Romaní, J. R. \& Santos, L. 2010: Palaeoenvironmental studies in NW Iberia (Cantabrian range): vegetation history and synthetic approach of the last deglaciation phases in the western Mediterranean. Palaeogeography, Palaeoclimatology, Palaeoecology $297,330-350$.

de Jong, R., Blaauw, M., Chambers, F. M., Christensen, T. R., de Vleeschower, F., Finsinger, W., Fronzek, S., Johansson, M., Kokfelt, U., Lamentowicz, M., Le Roux, G., Mauquoy, D., Mitchell, E. A. D., Nichols, J. E., Samaritani, E. \& van Geel, B. 2010: Climate and peatlands. In Dodson, J. (ed): Changing Climates, Earth Systems and Society, 85-121. Springer, Dordrecht.

Kaal, J., Costa-Casais, M., Ferro-Vázquez, C., Pontevedra-Pombal, X. \& Martínez-Cortizas, A. 2008: Soil formation of "Atlantic Rankers" from NW Spain-A high resolution aluminium and iron fractionation study. Pedosphere 18, 441-453.

Kuhry, P. 1985: Transgression of a raised bog across a coversand ridge originally covered with an oak-lime forest. Palaeoecological study of a Middle Holocene local vegetational succession in the Amstven (northwest Germany). Review of Palaeobotany and Palynology 44, 303-353.

Lappalainen, E. 1996: Global Peat Resources, 161 pp. International Peat Society, Finland, Jyskä.

Le Roux, G., Weiss, D., Grattan, J., Givelet, N., Krachler, M., Cheburkin, A., Rausch, N., Kober, B. \& Shotyk, W. 2004: Identifying the sources and timing of ancient and medieval atmospheric lead pollution in England using a peat profile from Lindow bog, Manchester. Journal of Environmental Monitoring $6,502-510$.

Linares, J. C. 2013: Shifting limiting factors for population dynamics and conservation status of the endangered English yew (Taxus baccata K., Taxaceae). Forest Ecology and Management 291, 119-127.

Lindsay, R. 1995: Bogs: The Ecology, Classification and Conservation of Ombrotrophic Mires, 120 pp. Scottish Natural Heritage, Edinburgh.

López-Merino, L., López-Sáez, J. A., Ruiz-Zapata, M. B. \& GilGarcía, M. J. 2008: Reconstructing the history of beech (Fagus sylvatica L.) in the north-western Iberian Range (Spain): from LateGlacial refugia to the Holocene anthropic-induced forests. Review of Palaeobotany and Palynology 152, 58-65.

López-Merino, L., Martínez-Cortízas, A. \& López-Sáez, J. A. 2010: Early agriculture and palaeoenvironmental history in the North of the Iberian Peninsula: a multi-proxy analysis of the Monte Areo Mire (Asturias, Spain). Journal of Archaeological Science 37, 19781988.

López-Sáez, J. A. \& López-Merino, L. 2007: Coprophilous fungi as a source of information of anthropic activities during the prehistory in the Amblés Valley (Avila, Spain): the archaeopalynological record. Revista Española de Micropaleontología 39, 103116.

López-Sáez, J. A., Sánchez-Mata, D., Alba-Sánchez, F., AbelSchaad, D., Gavilán, R. G. \& Pérez-Díaz, S. 2013: Discrimination of Scots pine forests in the Iberian Central System (Pinus sylvestris var. iberica) by means of pollen analysis. Phytosociologial considerations. Lazaroa 34, 191-208.

Lynn, W. C., McKinzie, W. E. \& Grossman, R. B. 1974: Field laboratory tests for characterization of Histosols. In Aandahl, A. R., Buol, S. W., Hill, D. E. \& Bailey, H. H. (eds.): Histosols: Their Characteristics, Classification, and Use, 11-20. Soil Science Society of America, Special Volume 6, Madison.

Magny, M. \& Haas, J. N. 2004: A major widespread climatic change around $5300 \mathrm{cal}$. yr BP at the time of the Alpine Iceman. Journal of Quaternary Science 19, 423-430.

Magri, D. 2008: Patterns of post-glacial spread and the extent of glacial refugia of European beech (Fagus sylvatica). Journal of Biogeography 35, 450-463.
Magri, D., Vendramin, G. G., Comps, B., Dupanloup, I., Geburek, T., Gömöry, D., Latalowa, M., Litt, T., Paule, L., Roure, J. M., Tantau, I., van der Knaap, W., Petit, R. J. \& de Beaulieu, J. L. 2006: A new scenario for the Quaternary history of European beech populations: palaeobotanical evidence and genetic consequences. New Phytologist 171, 199-221.

Mariscal, B. 1983: Estudio polínico de la turbera del Cueto de la Avellanosa, Poblaciones (Cantabria). Cadernos do Laboratorio Xeolóxico de Laxe: Revistade Xeoloxía Galega e do Hercínico Peninsular 5, 205-222.

Martínez-Atienza, F. \& Morla-Juaristi, C. 1992: Aproximación a la paleoecología holocena de Fagus en la Península Ibérica a través de datos polínicos. Investigaciones Agrarias, Sistemas y Recursos Forestales 1, 135-145.

Martínez-Cortizas, A., Mighall, T., Pontevedra-Pombal, X., NóvoaMuñoz, J. C., Peiteado-Varela, E. \& Piñeiro-Rebolo, R. 2005: Linking changes in atmospheric dust deposition, vegetation change and human activities in northwest Spain during the last 5300 years. The Holocene 15, 698-706.

Mercuri, A. M., Bandini, M., Florenzano, A., Montecchi, M. C. \& Rattighieri, E. 2013: Olea, Juglans and Castanea: the OJC group as pollen evidence of the development of human-induced environments in the Italian peninsula. Quaternary International 303, 24 42 .

Moore, P. D., Webb, J. A. \& Collinson, M. E. 1991: Pollen Analysis, 216 pp. Blackwell Scientific Publications, London.

Morales-Molino, C. \& García-Antón, M. 2014: Vegetation and fire history since the last glacial maximum in an inland area of the western Mediterranean basin (Northern Iberian Plateau, NW Spain). Quaternary Research 81, 63-77.

Morales-Molino, C., García-Antón, M. \& Morla, C. 2011: Late Holocene vegetation dynamics on an Atlantic-Mediterranean mountain in NW Iberia. Palaeogeography, Palaeoclimatology, Palaeoecology 302, 323-337.

Morales-Molino, C., García-Antón, M., Postigo-Mijarra, J. M. \& Morla, C. 2013: Holocene vegetation, fire and climate interactions on the westernmost fringe of the Mediterranean Basin. Quaternary Science Reviews 59, 5-17.

Moreno, A., López-Merino, L., Leira, M., Marco-Barba, J., González-Sampériz, P., Valero-Garcés, B. L., López-Sáez, J. A. Santos, L., Mata, P. \& Ito, E. 2011: Revealing the last 13,500 years of environmental history from the multiproxy record of a mountain lake (Lago Enol, northern Iberian Peninsula). Journal of Paleolimnology 46, 327-349.

van Mourik, J. M. 1986: Pollen profiles of slope deposits in the Galician area (N.W. Spain). Nederlandse Geografische Studies 12, 1171.

Muñoz-Sobrino, C. 2001: Cambio climático y dinámica del paisaje en las montañas del noroeste de la península. Ph.D. thesis, Universidad de Santiago de Compostela, 311 pp.

Muñoz-Sobrino, C., Ramil-Rego, P. \& Gomez-Orellana, L. 2007: Late Wurm and early Holocene in the mountains of northwest Iberia: biostratigraphy, chronology and tree colonization. Vegetation History and Archaeobotany 16, 223-240.

Muñoz-Sobrino, C., Ramil-Rego, P., Gómez-Orellana, L. \& DíazVarela, R. A. 2005: Palynological data on major Holocene climatic events in NW Iberia. Boreas 34, 381-400.

Muñoz-Sobrino, C., Ramil-Rego, P., Gómez-Orellana, L., Ferreiro de Costa, J. \& Díaz-Varela, R. A. 2009: Climatic and human effects on the post-glacial dynamics of Fagus sylvatica L. in NW Iberia. Plant Ecology 203, 317-340.

Muñoz-Sobrino, C., Ramil-Rego, P. \& Rodríguez-Guitián, M. 1997: Upland vegetation in the north-west Iberian Peninsula after the last glaciation: forest history and deforestation dynamics. Vegetation History and Archaeobotany 6, 215-233.

Muñoz-Sobrino, C., Suárez-Pérez, F. J., Nava-Fernández, H. S., Fernández-Casado, M. A., Gómez-Orellana, L., RodríguezGuitián, M. A., Fernández-Prieto, J. A. \& Ramil-Rego, P. 2012: Environmental changes in the westernmost Cantabrian Range during the postglacial period: the Pena Velosa (Muniellos, Asturias) pollen record. In Campar Almeida, A., Bettencourt, A. M. S., Moura, D., Monteiro-Rodrigues, S. \& Caetano Alves, M. I. (eds.): 
Environmental Changes and Human Interaction along the Western Atlantic Edge, 79-94. Associação Portuguesa para o Estudo do Quaternário, Coimbra.

Noryskiewicz, A. M. 2003: Modern pollen deposition in the Taxus reserve in the Wierzchlas (northern Poland). Abstract, 16th INQUA Congress, Reno, Nevada

Olazabal, L. 1856: Suelo, clima, cultivo agrario y forestal de la provincia de Vizcaya, 221 pp. Memorias de la Academia de las Ciencias, Madrid.

Ontañón, R., Altuna, J., Álvarez-Fernández, E., Chauvin, A., Cubas, M., Fernández, R., Gruet, Y., Iriarte, M. J., López-Dóriga, I., Mariezkurrena, K. \& Zapata, L. 2013: Contribution aà l'etude de la neolithisation dans la región Cantabrique. La grotte de Los Gitanos (Cantabrie, Espagne). In Daire, M. Y., Dupont, C., Baudry, A., Billard, C., Large, J. M., Lespez, L., Normand, E. \& Scarre, C. (eds): Anciens peuplements litoraux et relations Hommel Milieu sur les Côtes de L'Europe Atlantique, 383-390. BAR International Series, Oxford.

Peña-Chocarro, L. 2012: Neolithic, Chalcolithic and Bronze Age plant remains from El Mirón cave. Evidence on the first farming communities in the Cantabrian Region. In Straus, L. G. \& González-Morales, M. R. (eds.): El Miron cave. Cantabrian Spain. The Site and its Holocene Archaeological Record, 148-173. University of New Mexico, Albuquerque.

Peña-Chocarro, L., Zapata, L., Iriarte, M. J., González-Morales, M. R. \& Straus, L. G. 2005: The oldest agriculture in northern Atlantic Spain: new evidence from El Mirón Cave (Ramales de la Victoria, Cantabria). Journal of Archaeological Science 32, 579-587.

Peñalba, M. C. 1989: Dynamique de végétation tardiglaciaire et Holocène du centre-nord de l'Espagne d'après l'analyse pollinique. $\mathrm{Ph}$.D. thesis, Universidad d'Aix, $165 \mathrm{pp}$

Peñalba, M. C. 1994: The history of the Holocene vegetation in northern Spain from pollen analysis. Journal of Ecology 82, 815832.

Pérez-Díaz, S., López-Sáez, J. A. \& Galop, D. 2015: Vegetation dynamics and human activity in the Western Pyrenean Region during the Holocene. Quaternary International 364, 65-77.

Pérez-Díaz, S., López-Sáez, J. A., Ruiz-Alonso, M., Zapata, L. \& Abel-Schaad, D. 2013: Holocene history of Taxus baccata in the Basque Mountains (Northern Iberian Peninsula). Lazaroa 34, 2941.

Planelles, J. 1852: Ensayo de una flora fanerogámica gallega ampliada con indicaciones acerca de los usos medicinales de las especies que describen, 452 pp. Santiago de Compostela.

Pontevedra-Pombal, X., Mighall, T. M., Nóvoa-Muñoz, J. C., Peiteado-Varela, E., Rodríguez-Racedo, J., García-Rodeja, E. \& Martínez-Cortizas, A. 2013: Five thousand years of atmospheric $\mathrm{Ni}, \mathrm{Zn}, \mathrm{As}$, and Cd deposition recorded in bogs from NW Iberia: prehistoric and historic anthropogenic contributions. Journal of Archaeological Science 40, 764-777.

Pontevedra-Pombal, X., Nóvoa-Muñoz, J. C., García-Rodeja, E. \& Martínez-Cortizas, A. 2006: Mountain mires from Galicia (NW Spain). In Martini, I. P., Martínez-Cortizas, A. \& Chesworth, W. (eds): Peatlands: Evolution and Records of Environmental and Climatic Changes, 83-108. Elsevier, Dordrecht.

Pontevedra-Pombal, X., Rey-Salgueiro, L., García-Falcón, M., Martínez-Carballo, E., Simal-Gándara, J. \& Martínez-Cortizas, A. 2012: Pre-industrial accumulation of anthropogenic polycyclic aromatic hydrocarbons found in a blanket bog of the Iberian Peninsula. Environmental Research 116, 36-43.

Poska, A. \& Pidek, I. A. 2010: Pollen dispersal and deposition characteristics of Abies alba, Fagus sylvatica and Pinus sylvestris, Roztocze region (SE Poland). Vegetation, History and Archaeobotany 19, 91-101.

von Post, L. 1937: The geographical survey of Irish bogs. Irish Naturalist's Journal 6, 210-227.

Ramil-Rego, P. \& Aira, M. J. 1993: Estudio palinológico de la turbera de Pena Veira (Lugo). Anales del Jardín Botánico de Madrid $51,111-122$.

Ramil-Rego, P., Rodríguez-Gutián, M. A., Muñoz-Sobrino, C. \& Gómez-Orellana, L. 2000: Some considerations about the post- glacial history and recent distribution of Fagus sylvatica L. in the NW Iberian Peninsula. Folia Geobotánica 35, 241-271.

Reille, M. 1999: Pollen et spores d'Europe et d'Afrique du Nord, 535 pp. Laboratoire de Botanique Historique et Palynologie, Marseille.

Reimer, P. J., Bard, E., Bayliss, A., Beck, J. W., Blackwell, P. G., Bronk, Ramsey. C., Buck, C. E., Cheng, H., Edwards, R. L., Friedrich, M., Grootes, P. M., Guilderson, T. P., Haflidason, H., Hajdas, I., Hatté, C., Heaton, T. J., Hoffmann, D. L., Hogg, A. G., Hughen, K. A., Kaiser, K. F., Kromer, B., Manning, S. W., Niu, M., Reimer, R. W., Richards, D. A., Scott, E. M., Southon, J. R., Staff, R. A., Turney, C. S. M. \& van der Plicht, J. 2013: Intcal13 and marine 13 radiocarbon age calibration curves $0-50,000$ years cal BP. Radiocarbon 55, 1869-1887.

Rivas-Martínez, S. 1987. Memoria del MAPA de Series de Vegetación de España, escala 1:400.000, 268 pp. M.A.P.A. \& I.C.O.N.A., Madrid.

Rodríguez-Guitián, M. A., Ramil-Rego, P., Muñoz-Sobrino, C. \& Gómez-Orellana, L. 1996: Consideraciones sobre la migración holocena de Fagus a través de la Via Pirenaico-Cantábrica. In Ramil-Rego, P., Fernández-Rodríguez, C. \& Rodríguez-Guitián, M. A. (eds). Biogeografía Pleistocena-Holocena de la Península Ibérica, 98-111. Xunta de Galicia, Santiago de Compostela.

Roucoux, K. H., Shackleton, N. J., de Abreu, L., Schönfeld, J. \& Tzedakis, P. C. 2001: Combined marine proxy and pollen analyses reveal rapid Iberian vegetation response to north Atlantic millennial-scale climate oscillations. Quaternary Research 56, 128-132.

Rubiales, J. M., Ezquerra, J., Muñoz-Sobrino, C., Génova, M. M., Gil, L., Ramil-Rego, P. \& Gómez-Manzaneque, F. 2012: Holocene distribution of woody taxa at the westernmost limit of the Circumboreal/Mediterranean boundary: evidence from wood remains. Quaternary Science Reviews 33, 74-86.

Rubiales, J. M., García-Amorena, I., García-Álvarez, S. \& GómezManzaneque, F. 2008: The Late Holocene extinction of Pinus sylvestris in the Western Cantabrian Range (Spain). Journal of Biogeography 35, 1840-1850.

Rubiales, J. M., García-Amorena, I., Hernández, L., Génova, M., Martínez, F., Gómez-Manzaneque, F. \& Morla-Juaristi, C. 2010: Late Quaternary dynamics of pinewoods in the Iberian Mountains. Review of Palaeobotany and Palynology 162, 476-491.

Rubiales, J. M., Morla-Juaristi, C., Gómez-Manzaneque, F., GarcíaAlvarez, S., García Amorena, I., Génova, M., Martínez-García, F. \& Postigo, J. M. 2011: La historia holocena de los pinares montanos en la Cordillera Cantábrica. In Ezquerra, F. J. \& Reym, E. (eds.): Evolución del paisaje vegetal y el uso del fuego en la Cordillera Cantábrica, 110-124. Fundación Patrimonio Natural de Castilla y León, León.

Ruiz-Alonso, M. 2014: Evolución y explotación de los recursos vegetales desde el tardiglaciar en la vertiente mediterránea del País Vasco: Datos antracológicos, 589 pp. Universidad del País Vasco, Vitoria-Gasteiz.

Ruiz-Urrestarazu, E. 1989: Pinares reliquia en el monte Gorbea. Sustrai $14,66-67$.

Sánchez-Goñi, M. F. 1988: A propos de la présence du pollen de Castanea et Juglans dans les sédiments archéologiques würmiens anciens du Pays Basque espagnol. Travaux de la Section Scientifique et Technique Institut de Pondichéry XXV, 73-82.

Santos, L., Vidal-Romaní, J. R. \& Jalut, G. 2000: History of vegetation during the Holocene in the Courel and Queixa Sierras, Galicia, northwest Iberian Peninsula. Journal of Quaternary Science $15,621-632$.

Shotyk, W. 1996: Peat bog archives of atmospheric metal deposition: geochemical evaluation of peat profiles, natural variations in metal concentrations, and metal enrichment factors. Environmental Reviews 6, 149-183.

Shotyk, W., Krachler, M., Martinez-Cortizas, A., Cheburkin, A. K. \& Emons, H. 2002: A peat bog record of natural, preanthropogenic enrichments of trace elements in atmospheric aerosols since $12,370{ }^{14} \mathrm{C}$ yr BP, and their variation with Holocene climate change. Earth and Planetary Science Letters 199, $21-37$. 
Silva-Sánchez, N., Martínez-Cortizas, A. \& López-Merino, L. 2014: Linking forest cover, soil erosion and mire hydrology to late-Holocene human activity and climate in NW Spain. The Holocene 24, 714-725.

Sjögren, P. 2006: The development of pastures woodland in the southwest Swiss Jura Mountains over 2000 years, based on the three adjacent peat profiles. The Holocene 16, 210-223.

Sjögren, P. \& Lamentowicz, M. 2008: Human and climatic impact on mires: a case study of les Amburnex mire, Swuiss Jura Mountains. Vegetation History and Archaeobotany 17, 185-197.

Soil Survey Staff. 1975: Soil Taxonomy. USDA-SCS Agricultural Handbook 436, 754 pp. US Government, Washington, DC.

Stoll, H. M., Moreno, A., Mendez-Vicente, A., Gonzalez-Lemos, S., Jimenez-Sanchez, M., Dominguez-Cuesta, M. J., Edwards, R. L., Cheng, H. \& Wang, X. 2013: Paleoclimate and growth rates of speleothems in the northwestern Iberian Peninsula over the last two glacial cycles. Quaternary Research 80, 284-290.

Tinner, W. \& Lotter, A. F. 2006: Holocene expansion of Fagus sylvatica and Abies alba in central Europe. Where are we after eight decades of debate? Quaternary Science Reviews 25, 526-549.

Uribe-Etxebarria, P. M., Zorrakin, I., Campos, J. A. \& Domínguez, A. 2006: Flora vascular amenazada en la Comunidad Autónoma del País Vasco, 389 pp. Gobierno Vasco, Vitoria-Gasteiz.

Uzquiano, P., Allue, E., Antolín, F., Burjachs, F., Picornell, L. L., Pique, R. \& Zapata, L. 2014: All about yew: on the trail of Taxus baccata in southern Europe by means of integrated palaeobotanical and archaeobotanical studies. Vegetation History and Archaeobotany 24, 229-247.

Valsecchi, V., Finsinger, W., Tinner, W. \& Amman, B. 2008: Testing the influence of climate, human impact and fire on the Holocene population expansion of Fagus sylvatica in the southern Prealps. The Holocene 18, 603-614.

Wardenaar, E. P. C. 1987: A new hand tool for cutting peat profiles. Canadian Journal of Botany 65, 1172-1173.

Watts, W. A. 1973: Rates of change and stability in vegetation in the perspective of long periods of time. In Birks, H. J. B. \& West, R. G. (eds): Quaternary Plant Ecology, 195-206. Blackwell, Oxford.
Willkomm, H. M. \& Lange, J. M. C. 1861: Prodromus Florae Hispanicae Seu Synopsis Methodica Omnium Plantarum in Hispania Sponte Nascentium Vel Frequentis Cultarum Quae Innotuerunt I, 356 pp. Nabu Press, Stuttgart.

Wright, H. E. \& Patten, H. J. 1963: The pollen sum. Pollen et Spores $5,445-450$

Zaccone, C., Cocozza, C., Cheburkin, A. K., Shotyk, W. \& Miano, T. M. 2008: Distribution of As, Cr, Ni, Rb, Ti and Zr between peat and its humic fraction along an undisturbed ombrotrophic bog profile (NW Switzerland). Applied Geochemistry 23, 25-33.

Zapata, L. 2001: El uso de los recursos vegetales en Aizpea (Navarra, Pirineo Occidental): la alimentación, el combustible y el bosque. In Barandiarán-Maestu, I. \& Cava, A. (eds.): Cazadores-recolectores en el Pirineo navarro: el sitio de Aizpea entre 8.000 y 6.000 BP, 325-359. Universidad del País Vasco, Vitoria-Gasteiz.

Zapata, L. 2002: Origen de la agricultura en el País Vasco y transformaciones en el paisaje: Análisis de los restos vegetales arqueológicos, 223 pp. Kobie (Anejo 4). Diputación Foral de Bizkaia, Bilbao.

Zapata, L. 2012: Holocene wood charcoal from El Mirón cave. Vegetation and wood use. In Straus, L. G. \& González-Morales, M. R. (eds.): El Miron cave. Cantabrian Spain. The Site and its Holocene Archaeological Record, 174-196. University of New Mexico, Albuquerque.

Zapata, L. \& Peña-Chocarro, L. 2013: Crops and people. Diffusion of farming in South-Western Europe. In Blasco, E., Francalecci, P., Nocentini, A. \& Tandaa, G. (eds.): Iberia e Sardegna, 277-288. Le Monier Universitá, Cagliari.

Zapata, L., Ibáñez, J. J. \& González, J. E. 1997: El yacimiento de la cueva de Kobaederra (Oma, Kortezubi, Bizkaia). Resultados preliminares de las campañas de excavación 1995-97. Munibe (Antropologia-Arkeologia) 49, 51-63.

Zapata, L., Milner, N. J. \& Roselló, E. 2007: Pico Ramos cave shell midden: the Mesolithic-Neolithic transition by the Bay of Biscay. In Milner, N., Craig, O. E. \& Bailey, G. N. (eds): Shell Middens in Atlantic Europe, 150-157. Oxbow Books, Oxford.

Zapata, L., Peña-Chocarro, L., Pérez-Jordá, G. \& Stika, H. P. 2004: Early Neolithic agriculture in the Iberian Peninsula. Journal of World Prehistory 18, 283-325. 